\title{
Amended Description of Haemophilus segnis Kilian 1977
}

\author{
M. KILIAN AND J. THEILADE \\ Departments of Microbiology and Electron Microscopy, Royal Dental College, Aarhus, Denmark
}

\begin{abstract}
A detailed amended description of Haemophilus segnis Kilian 1977 based on an examination of 22 strains, including the type strain, is presented. Included is information on ultrastructural characteristics, biochemical activities, fermentation end products, and deoxyribonucleic acid base composition.
\end{abstract}

In a recent taxonomic study of 426 Haemophilus strains from human and animal origin, 17 strains isolated primarily from human saliva and dental plaque formed a separate group on the basis of their biochemical and other characteristics. The cell morphology, Gram reaction, requirement for the $\mathrm{V}$-factor (nicotinamide adenine dinucleotide), and the ability to reduce nitrate confirmed its inclusion in the genus $\mathrm{Hae}$ mophilus. The distinguishing characteristics of this taxon, i.e., its feeble biochemical activity and the relatively high guanine-plus-cytosine $(\mathrm{G}+\mathrm{C})$ content of its deoxyribonucleic acid (DNA) $(43.5 \pm 0.54 \mathrm{~mol} \%)$ seemed to justify its recognition as a separate species within that genus. The name Haemophilus segnis (L. adj. segnis sluggish) was proposed (5). The name was validly published in the International Journal of Systematic Bacteriology (3).

The present report provides an extended description of the biochemical and ultrastructural characteristics of $H$. segnis.

\section{MATERIALS AND METHODS}

Bacterial strains. The 22 strains on which this report is based consist of 17 strains previously examined (5) (HK 35, HK 84, HK 87, HK 106, HK 114, HK 127, HK 129, HK 131, HK 135, HK 149, HK 161, HK 307 , HK 313, HK 314, HK 316, HK 317, and HK 320) plus 5 fresh isolates (HK 497, HK 498, HK 499, HK 500 , and HK 501). The origins of the strains are given in Table 1.

Cultural and biochemical methods. The methods used to determine the cultural and biochemical characteristics of the strains were described previously $(4,5)$.

Electron microscopy. Strain HK 316, the type strain, was cultured on chocolate agar $(10 \%$ heated defibrinated horse blood in blood agar base [Difco]). After incubation for 2 days in air plus $10 \% \mathrm{CO}_{2}$, a layer of $1.5 \%$ agar $\left(45^{\circ} \mathrm{C}\right)$ in Veronal acetate buffer $(\mathrm{pH} 6.1)$ was poured over the surface colonies and allowed to solidify. Small blocks containing the bacterial colonies were cut out and fixed in buffered glutaraldehyde and osmium tetroxide, block-stained in uranyl acetate, dehydrated, and finally embedded in Epon as previously described (6). Thin sections were cut through the colonies perpendicular to the original agar surface.
The sections were poststained with uranyl magnesium acetate (1) and lead citrate (10) and examined in a Philips EM 200 or EM 301 electron microscope at 60 $\mathrm{kV}$.

Determination of fermentation products. Analyses of glucose fermentation products were performed in a Hewlett-Packard gas chromatograph model 5830A (Würtenberg, Germany). The conditions of analysis were: hydrogen flame detector; oven temperature, $130^{\circ} \mathrm{C}$; coiled glass column $(1.8 \mathrm{~m}$ by $4 \mathrm{~mm}$ inner diameter) packed with 80- to 100 -mesh Chromosorb G, AW, DMCS (Johns-Manville, Denver, Colo.); stationary phase, 5\% FFAP (Jydsk Teknologisk Institut, Aarhus, Denmark); and nitrogen flow rate, $60 \mathrm{ml} / \mathrm{min}$. Ether and chloroform extracts of 5-day-old glucose broth cultures were performed by the method described by Holdeman and Moore (2). The glucose broth contained (per liter): $10 \mathrm{~g}$ of neutralized bacteriological peptone (L 34, Oxoid Ltd., London); $10 \mathrm{~g}$ of yeast extract powder (L 21, Oxoid Ltd., London); $10 \mathrm{~g}$ of glucose; $10 \mathrm{mg}$ of nicotinamide adenine dinucleotide (Sigma, St. Louis, Mo.); and salt solution as described by Holdeman and Moore (2).

\section{RESULTS}

A description of $H$. segnis Kilian 1977 follows. Cell characteristics. Gram-negative, nonmotile, nonsporeforming, non-encapsulated, pleomorphic rods, often showing a predominance of irregular filamentous forms.

Uitrastructure. Examination of thin sections of the organism revealed cells with round or elongated profiles suggesting that the population comprised coccal or rod-shaped bacteria (Fig. 1). The cytoplasm was characterized by a peripheral zone of ribosomes and a central, less electron-dense area representing the nuclear region

TABLE 1. Sources of 22 strains of Haemophilus segnis

\begin{tabular}{lcl}
\hline \multicolumn{1}{c}{$\begin{array}{c}\text { Strains } \\
\text { (HK no.) }\end{array}$} & $\begin{array}{c}\text { No. of } \\
\text { strains }\end{array}$ & \multicolumn{1}{c}{$\begin{array}{c}\text { Source } \\
\text { (human) }\end{array}$} \\
\hline 35,501 & 2 & Pharynx \\
$84,87,106,114,127,129$, & 14 & Saliva \\
$131,135,149,161,497$, & & \\
$498,499,500$ & & Dental plaque \\
\hline $307,313,314,316,317,320$ & 6 & \\
\hline
\end{tabular}




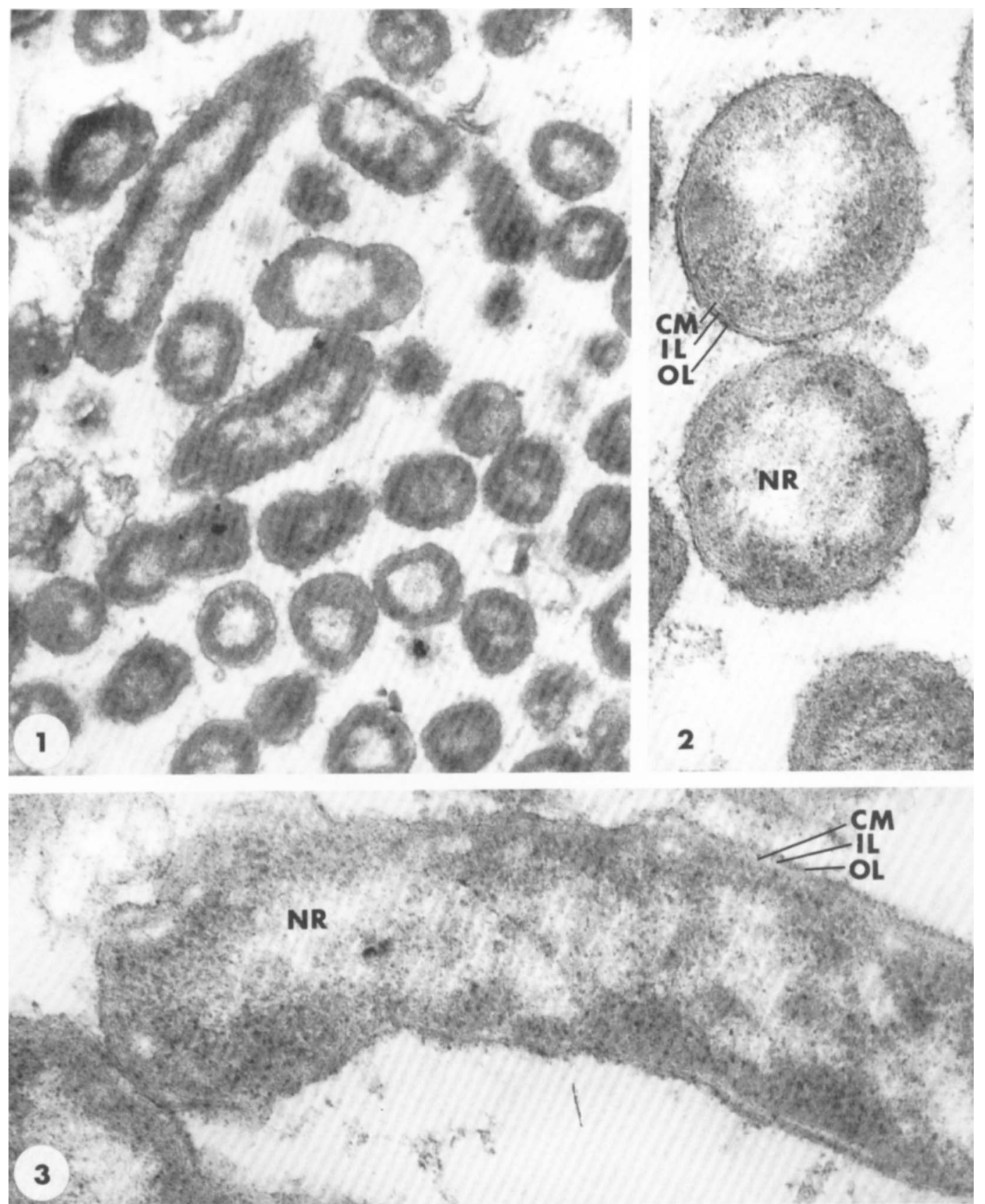

FIG. 1. Thin section of colony of $H$. segnis strain $H K 316$ revealing round or elongated cells. Magnification, $\times 29,000$.

FIG. 2 and 3. Thin sections of $H$. segnis strain $H K$ 316. The cells are surrounded by a cell wall comprising a triple-layered outer membrane $(O L)$ and a thin intermediate layer (IL) of medium electron density interposed between the outer membrane and the cytoplasmic membrane (CM) of the cell. The cytoplasm contains ribosomes distributed in a less dense matrix except for the centrally located nuclear region (NR). 
TABLE 2. Biochemical characteristics of Haemophilus segnis, including the type strain

\begin{tabular}{|c|c|c|c|}
\hline \multirow{2}{*}{ Test or substrate ${ }^{a}$} & \multicolumn{2}{|c|}{ H. segnis $(N=22)^{b}$} & \multirow{2}{*}{$\begin{array}{l}\text { Strains which gave negative } \\
\text { results }\end{array}$} \\
\hline & $\begin{array}{c}\text { No. of strains which gave a pos- } \\
\text { itive result }\end{array}$ & $\begin{array}{c}\text { Type strain } \\
\text { (HK } 316=\text { NCTC 10977) }\end{array}$ & \\
\hline NAD requirement & 22 & + & \\
\hline ALA $\rightarrow$ porphyrine & 22 & + & \\
\hline Indole production & 0 & - & \\
\hline Urease & 0 & - & \\
\hline Ornithine decarboxylase & 0 & - & \\
\hline Lysine decarboxylase & 0 & - & \\
\hline Arginine dihydrolase & 0 & - & \\
\hline Hemolysis, calf blood & 0 & - & \\
\hline $\mathrm{H}_{2} \mathrm{~S}($ lead acetate $)$ & 0 & - & \\
\hline Nitrate reduction & 22 & + & \\
\hline Catalase & $(13)^{c}$ & - & $\begin{array}{c}\text { HK } 106,114,127,129, \\
131,161,313,314,320\end{array}$ \\
\hline Oxidase & 0 & - & \\
\hline$\beta$-Galactosidase (ONPG) & 12 & - & $\begin{array}{l}\text { HK } 127,129,307,316 \text {, } \\
\quad 317,497,498,499,500 \\
\quad 501\end{array}$ \\
\hline$\alpha$-Fucosidase (PNPF) & 0 & - & \\
\hline Alkaline phosphatase & 22 & + & \\
\hline L-(+)-Arabinose, acid & 0 & - & \\
\hline D-Ribose, acid & 0 & - & \\
\hline D- $(+)-X y l o s e$, acid & 0 & - & \\
\hline L-(+)-Rhamnose, acid & 0 & - & \\
\hline D-(+)-Galactose, acid & $(18)$ & $(+)$ & HK 106, 307, 316, 317 \\
\hline Glucose, acid & $(22)$ & $(+)$ & \\
\hline Glucose, gas & 0 & - & \\
\hline D-Fructose, acid & $(22)$ & $(+)$ & \\
\hline D-(+)-Mannose, acid & $(21)$ & $(+)$ & HK 497 \\
\hline Sorbose, acid & 0 & - & \\
\hline Cellobiose, acid & 0 & - & \\
\hline Lactose, $1 \%$, acid & 0 & - & \\
\hline Lactose, $5 \%$, acid & 0 & - & \\
\hline Maltose, acid & $(22)$ & $(+)$ & \\
\hline Melibiose, acid & 0 & - & \\
\hline Sucrose, acid & $(22)$ & $(+)$ & \\
\hline Trehalose, acid & 0 & - & \\
\hline Melizitose, acid & 0 & - & \\
\hline Raffinose, acid & 0 & - & \\
\hline Inulin, acid & 0 & - & \\
\hline Starch, soluble, acid & 0 & - & \\
\hline Esculin, acid & 0 & - & \\
\hline Salicin, acid & 0 & - & \\
\hline Adonitol, acid & 0 & - & \\
\hline Dulcitol, acid & 0 & - & \\
\hline Glycerol, acid & (18) & $(+)$ & HK $35,84,87,129$ \\
\hline meso-erythritol, acid & 0 & - & \\
\hline Mannitol, acid & 0 & - & \\
\hline Sorbitol, acid & 0 & - & \\
\hline Inositol, acid & 0 & - & \\
\hline Xylitol, acid & 0 & - & \\
\hline $\begin{array}{l}\text { Acid end products in glu- } \\
\text { cose broth }\end{array}$ & Acetic, lactic, succinic & Acetic, lactic, succinic & \\
\hline Final $\mathrm{pH}$ in glucose broth & $6.4-7.0$ & 6.8 & \\
\hline $\mathrm{G}+\mathrm{C}$ content $(\mathrm{mol} \%)$ & $43.5 \pm 0.54$ & $42.7 \pm 0.26$ & \\
\hline
\end{tabular}

${ }^{a}$ Abbreviations: NAD, nicotinamide adenine dinucleotide; ALA, $\delta$-aminolaevulinic acid.

${ }^{b} N$, Number of strains studied.

${ }^{c}$ Parentheses indicate weak reactions. 
TABLE 3. Diagnostic and differential characteristics of Haemophilus segnis and two related species

\begin{tabular}{|c|c|c|c|c|c|c|c|c|c|c|c|c|}
\hline Species & $\begin{array}{c}\mathrm{NAD}^{a} \\
\text { require- } \\
\text { ment }\end{array}$ & $\begin{array}{c}\mathrm{ALA}^{b} \\
\overrightarrow{\text { phyrine }} \\
\text { phyr- }\end{array}$ & Urease & $\begin{array}{c}\text { Orni- } \\
\text { thine } \\
\text { decar- } \\
\text { boxy- } \\
\text { lase }\end{array}$ & $\begin{array}{l}\text { Hemol- } \\
\text { ysis, calf } \\
\text { blood }\end{array}$ & $\begin{array}{l}\text { Glu- } \\
\text { cose, } \\
\text { acid }\end{array}$ & $\begin{array}{l}\text { Glu- } \\
\text { cose, } \\
\text { gas }\end{array}$ & $\begin{array}{l}\text { Su- } \\
\text { crose, } \\
\text { acid }\end{array}$ & $\begin{array}{l}\text { Lactose, } \\
\text { acid }\end{array}$ & $\begin{array}{c}\text { Ribose, } \\
\text { acid }\end{array}$ & $\begin{array}{c}\alpha-\mathrm{Fu}- \\
\text { cosidase }\end{array}$ & $\begin{array}{l}G+C \text { con- } \\
\text { tent of } \\
\text { DNA }\end{array}$ \\
\hline H. segnis & + & + & - & - & - & $\mathbf{w}$ & - & $\mathbf{w}$ & - & - & - & $43.5 \%$ \\
\hline $\begin{array}{l}\text { H. parain- } \\
\text { fluenzae }^{c}\end{array}$ & + & + & d & d & $d$ & + & d & + & - & - & - & $40.2 \%$ \\
\hline H. parasuis ${ }^{c}$ & + & + & - & - & - & + & - & + & - & + & + & $41.5 \%$ \\
\hline
\end{tabular}

${ }^{a}$ NAD, Nicotinamide adenine dinucleotide.

${ }^{b}$ ALA, $\delta$-aminolaevulinic acid.

${ }^{c}$ Results compiled from Kilian (5).

(Fig. 2 and 3). Cytoplasmic inclusions were not observed. External to the cytoplasmic membrane, a cell wall was present consisting of a narrow electron-thin intermediate layer and, peripherally, a triple-layered outer membrane, which in some of the cells exhibited a slightly wavy course. Thus the organism displayed the typical ultrastructure reported for gram-negative bacteria (9). No cellular appendages such as flagella or pili were seen.

Surface colonies. Colonies on chocolate agar were smooth or granular, convex, grayish-white, and opaque and reached a diameter of about 0.5 $\mathrm{mm}$ after incubation for $48 \mathrm{~h}$. No odor was emitted from the growth. Satellite growth was obtained on blood agar cross-inoculated with a staphylococcus. No hemolysis was produced on blood-agar media.

Growth-factor requirements. Requires Vfactor (nicotinamide adenine dinucleotide or one of its riboside precursors) but not X-factor (hemin). Produces porphyrins from $\delta$-aminolaevulinic acid.

Relationship to oxygen. Aerobic, facultatively anaerobic. Additional $\mathrm{CO}_{2}$ is not required for growth in air.

Biochemical reactivity. Chemoheterotrophic. Biochemical activities are listed in Table 2.

Fermentation end products. Acetic, lactic, and succinic acids are produced in glucose broth. Hydrogen and $\mathrm{CO}_{2}$ are not produced.

$\mathbf{G}+\mathbf{C}$ content of DNA. The $\mathrm{G}+\mathrm{C}$ content of the DNA was $43.5 \pm 0.54 \mathrm{~mol} \%\left(T_{m}\right)$ (mean value for four strains: HK 35 , HK 84 , HK 307 , and HK 316).

Source. To date, isolated from the oral cavity and pharynx of humans. The primary habitat of this organism is probably dental plaque (6).

Type strain. The type strain is HK 316 . This strain has been deposited in the National Collection of Type Cultures, Colindale, London, as NCTC 10977, and in the Czechoslovak Collection of Microorganisms, Brno, as CCM 6052. It was isolated from human dental plaque.

\section{DISCUSSION}

The relatively high content of $\mathrm{G}+\mathrm{C}$ in the DNA of strains of $H$. segnis is one of the distinctive characteristics of this species. $\mathrm{G}+\mathrm{C}$ values are not as yet characters on which a practical identification may be based. However, several biochemical features, mainly of negative nature, distinguish this species from other $\mathrm{V}$-dependent and X-independent Haemophilus species. The characters which are most useful in the separation of $H$. segnis from the two most related species, $H$. parainfluenzae and $H$. parasuis, are provided in Table $3 . H$. segnis in many ways resembles $H$. parasuis. However, besides the differences listed in Table 3 and the different habitat of the two species, $H$. parasuis grows very poorly on most media used for the isolation of haemophili.

Like $H$. parainfluenzae, and partly like $H$. paraphrophilus and $H$. aphrophilus, $H$. segnis is indigenous to the human oral cavity, where tooth surfaces seem to be its primary habitat (6). The pathogenicity of the organism is yet unknown. However, its presence in dental plaque makes it a likely potential cause of bacterial endocarditis. Several cases of bacterial endocarditis due to the other Haemophilus species found in the oral cavity are on record (5).

\section{ACKNOWLEDGMENT}

This study was supported by grant no. 51-25151 from the Danish State Medical Research Council.

\section{REPRINT REQUESTS}

Address reprint requests to: Dr. M. Kilian, Department of Microbiology, Royal Dental College, Vennelyst Blvd., DK8000 Aarhus C, Denmark.

\section{LTERATURE CITED}

1. Frasca, J. M., and V. R. Parks. 1965. A routine technique for double-staining ultrathin sections using uranyl and lead salts. J. Cell Biol. 25:157-161.

2. Holdeman, L. V., and W. E. C. Moore. 1972. Anaerobe laboratory manual. Anaerobe Laboratory, Virginia Polytechnic Institute \& State University, Blacksburg, Va. 
3. International Association of Microbiological Societies. 1977. Announcement of the valid publication of new names and new combinations previously effectively published outside the IJSB. List no. 1. Int. J. Syst. Bacteriol. 27:306

4. Kilian, M. 1974. A rapid method for the differentiation of Haemophilus strains. The porphyrin test. Acta Pathol. Microbiol. Scand. Sect. B 82:835-842.

5. Kilian, M. 1976. A taxonomic study of the genus Hae. mophilus, with the proposal of a new species. J. Gen. Microbiol. 93:9-62.

6. Kilian, M., and C. R. Schiøtt. 1975. Haemophili and related bacteria in the human oral cavity. Arch. Oral Biol. 20:791-796.

7. Kilian, M., and J. Theilade. 1975. Cell wall ultrastruc- ture of strains of Haemophilus ducreyi and Haemophilus piscium. Int. J. Syst. Bacteriol. 25:351-356.

8. Lapage, S. P., P. H. A. Sneath, E. F. Lessel, V. B. D. Skerman, H. P. R. Seeliger, and W. A. Clark (ed.). 1976. International code of nomenclature of bacteria, 1976 revision. American Society for Microbiology, Washington, D.C.

9. Murray, R. G. E. 1962. Fine structure and taxonomy of bacteria, p. 119-144. In G. B. Ainsworth and P. H. A. Sneath (ed.), Microbial classification. Twelfth Symposium of the Society of General Microbiology. University Press, Cambridge.

10. Reynolds, E. S. 1963 . The use of lead citrate at high $\mathrm{pH}$ as an electron-opaque stain in electron microscopy. J. Cell Biol. 17:208-212. 